\title{
METHODOLOGY AS AN IMPORTANT VALUE OF POLITICAL SCIENCE RESEARCH
}

\author{
by Andrzej Chodubski
}

In reality of getting stronger influence of shaping the cultural and civilization mass-media image, human studies are facing new challenges. It is observed that the mass-media are trying to replace some of the sciences, namely the political science.

In the practice of cultural life, we can notice the blurring of the borders between mass-media knowledge and actual science. The media commentary of political life is trying to become a research work.

The marginalization of the methodology research in the political science leads to deformation of its own science creation. In the scientific recognition of socio-political reality, the methodology is responsible for creating theories, based on defining terms, methodological knowledge ordering, explaining and interpreting the knowledge according to particular rules, models, paradigms, etc.

The political study is determining its own identity (never fully revealed and fluent), like other studies and sciences, it constantly improves the methodological researches, it is looking for conceptual terms, methods, problems, settlements, schemes that simultaneously cause the escape from the stagnation and ageing. In the past few years we can notice the develop- 
ment of theoretical movement in political science, which aim is to synthesize different visions of society and social unit evolution. ${ }^{1}$

In this perspective the particular place is assigned to the global pictures, i.e. in the reference to the past - the need of using theoretical knowledge is being improved, in the reference to the present - after the facts identification, creating synthesis of research results, and in the reference to the future - the goal is to place the phenomena in the long term perspective, on the background of wider social development, expecting the evolution alternatives.

Both in the political recognition and in many science disciplines it is important to pay attention to:

1. The withdrawal from narrow empiric and factographic testing in favor of building general theoretical synthesis;

2. The withdrawal from analysis of the statistical system models in favor of the dynamic and gradual character of social and political life, which remains in the process of 'becoming itself';

3. The withdrawal from structural or environmental determinism in favor of reflecting individual and collective objects (for example charismatic leaders or social movements) in initiating or blocking changes;

4. The withdrawal from micro-social analysis and rebirth of macrostructures and macro-processes of the classical interests (made for example in the $19^{\text {th }}$ century);

5. The decrease of 'hard' problems of institutions, social organizations in favor of 'soft' culture problems: systems of values, rules, social mentality, etc.;

6. The withdrawal from the 'fashion' of mass media and representative researches, like polls in favor of paying attention to the quality and interpretation methods, to the of studies hermeneutics of particu-

1 T. Klementewicz, Spór o model metodologiczny nauki o polityce, Warszawa 1991, p. 133; Cz. Mojsiewicz, Rozmowy o polskiej politologii, Toruń 2005; A. Żukowski, Politologia jako dyscyplina naukowa i kierunek kształcenia. Zarys problematyki, Olsztyn 2006; Problemy badawcze i metodologiczne politologii w Polsce, A.J. Chodubski, M.J. Malinowski (eds.), Gdańsk 2006. 
lar cases and sources, and changes of major rules in describing reality connected with it. ${ }^{2}$

The importance of theory building in the political science stems from the essence of creating researches. The points is to look for generalizations and therefore the withdrawal from practice although, it is giving the background for generalizations. Science is not a set of defined terms commonly known as factology or factography, but it is the interpretation of connections, rules and laws already existing and occurring between events, facts, phenomena and processes. ${ }^{3}$ A set of information not being generalizations or theory is called the knowledge, it can be characterized by the coincidence in choosing insight or incomplete criticism. The knowledge is a product for science.

In the process of building science theories it is important to detect regularities and specificity of events and processes in social life on different levels of generalizations. In this case, a valuable thing is to place events, social, political and economical processes in long term perspective, for example on the background of present scientist transformations made under the influence of modern technical revolution.

On the other hand, by getting to know the regularity and peculiarity of events and processes, in the synthesis and analysis, the connection between present and past should be reflected. In this case the opinion, that not knowing the past inveritably results from misunderstanding of present times, is persuasive. ${ }^{4}$

In the political science each theory should be universal and open for new facts, events, phenomena, processes and new theoretical problems,

2 P. Sztompka, Przyszłość nauk społecznych i humanistycznych w Polsce, [in:] Nauka $w$ Polsce w perspektywie XXI wieku, Warszawa 1996, pp. 305-306; P. Pawełczyk, Socjotechniczne aspekty gry politycznej, Poznań 2003; R. Dyoniziak, Sondaże a manipulowanie społeczeństwem, Toruń 2004; A. Chodubski, Standardy światowe a tendencje rozwojowe współczesnej politologii w Polsce, [in:] Politologia w Polsce. Stan badań i perspektywy, M. Cichosz, K. Zamorska (eds.), Wrocław 2006, pp. 65-81.

3 Cf. O. Cetwiński, Teoria narracji politologicznej, Warszawa-Zielona Góra 2002, ch.I.; A. Chodubski, Wstęp do badań politologicznych, Gdańsk 2008, ch.I.

4 G. Barraclough, Wstęp do historii współczesnej, Warszawa 1971, p. 27; Z.J. Pietraś, Podstawy teorii stosunków międzynarodowych, Lublin 1986, pp. 24-25; J. Apanowicz, Metodologia nauk, Toruń 2003, p. 35. 
it should also enable versatile picture of cultural and civilization reality, versatile in that case means simultaneously:

1. Global (recreating the dynamic of phenomena and its place in particular structure);

2. Integral (both in the categories of human activity and in its results);

3. Explanatory (theoretical, nomological - i.e. in the categories and classes of facts). ${ }^{5}$

In political science as well as in other science disciplines the theory building depends on methodological consciousness and research responsibility. The methodological knowledge is treated by scientists as something less important. In the cognition we can observe the submission of reflection on particular state of affairs to using research methods. For many scientists the tradition and the respect for authorities is more important than using well-known methods or logical thinking in revealing and checking if it is correct. ${ }^{6}$ In the consequence it leads to revealing dogmatism, trivialization and rejection of value in the cognition. Underestimating of methodology can be seen in polish political science. ${ }^{7}$

The knowledge about civilization, one of the youngest human science is facing the challenge of the synthetic and global cognitions. Its individuality was not defined until the $20^{\text {th }}$ century ${ }^{8}$. Its object of study is to look for laws that govern the civilization processes and events, both in time and space. With reference to explaining the cultural and civilization

5 T. Klementewicz, op.cit., p. 141; S.D. Tansey, Nauki polityczne, Poznań 1997, pp. 19-24; G. Babiński, Metodologia a rzeczywistość społeczna. Dylematy badań etnicznych, Kraków 2004; M. Sułek, Metody i techniki badań stosunków międzynarodowych, Warszawa 2004.

6 J. Such, Wstęp do metodologii ogólnej nauk, Poznań 1973, p. 8; Z. Hajduk, Ogólna metodologia nauk, Lublin 2001, p. 4; D. Mider, Partycypacja polityczna w Internecie, Warszawa 2008; T. Buksiński, Prawo a władza polityczna, Poznań 2009.

7 Cf. B. Krauz-Mozer, Metodologiczne problemy wyjaśniania w nauce o polityce, Kraków 1992; A. Chodubski, O świadomości metodologicznej w politologicznym poznaniu, „Teoria i Praktyka Polityki” 1995, No. 1, pp. 29-36; A. Łuszczyński, Podstawy metodologiczne badań politologicznych, Rzeszów 2005, ch. III.

8 Cf. A. Piskozub, Elementy nauki o cywilizacji, Gdańsk 1992, Idem, Cywilizacje w czasie i przestrzeni, Gdańsk 1996; „Cywilizacja i Polityka” 2003-2008, No. 1-6. 
development, there are often three main ideas of laws, which govern its course. The first one assumes that the cultural process is a cyclical process, i.e. in particular time similar situations and events return to similar forms of authority and are connected with these social and political ideas. The second one is a form of antithesis of the cyclic world progress. It assumes that there is a linear evolution of the world, i.e. links of situations and events seen as a destiny or as being the product of particular circumstances and time. The third one assumes the synthesis of periods and progresse, which means it acknowledges the cyclical development, in which general stadia are repeated. The linear progress can be seen in all stadia. This evolution is called spiral, for its graphic presentation.

In the cognition the civilization study aims to synthetic presentations. It is using the wild horizons of time and space. By the term civilization we understand the level of society development in particular historical period. This evolution is conditioned by the human control of nature, the technology condition, the pattern in social and political relationships and also by the place of human being in those references.

In the cognition, the civilization study makes use of various science disciplines, among others: history, human geography, sociology, law, economy, from which it takes so called inputs, the informational contribution. The holistically integrated and processed information made the foundations of disciplines. And so, the history by getting to know facts about the past, inquiring into the authenticity and credibility of those facts, and collecting them into the historical process by establishing the correctness and laws of the social development, gives the picture of particular civilization in time to the civilization science. Until the $20^{\text {th }}$ century general information ordering belongs to philosophy or to philosophy of history. Fact-findings within this domain often rose interpretative controversies because they transcend beyond the sphere of scientific verifiability. In the study of civilisation, where historical fact-findings are used, one, first of all, pays attention to so called relations between civilisations in time.

The human geography by getting to know the space, phenomena of social and political processes and effects of natural Earth shape on these processes, and vice versa, provides the information about the civilizations in space. 
The clarification of socio-political phenomena with the use of geography and natural sciences, and geographical and nature sciences with the use of humanities is the controversial thing in the area of study. Lew Gumilow, a scientist, paid attention to this problem. He explained the range of Russian Empire with the help of geography and natural science. He used the January isotherm, which delimits territory into negative (Russia) and positive (superetnos romano-germanic) average of temperatures. ${ }^{9}$

In spite of many controversies, especially of political nature, the geographical and nature feature is noticed as an important determinant of all attitudes and socio-political behaviors, both on global and local scale. The civilization study refers to this factor as an important element determining the economical, social and political changes.

The sociology by studying the phenomena and processes of creating collective forms of human being's life, structures of these communities, phenomena and processes that occur in them (resulted from human interactions), converging and breaking powers of these communities, changes and transformations happening in them, gives the main contents of the civilization theory. The foundations of the sociology establishments provide the material for further generalizations in the sphere of the civilization science. So, the sociology constitutes characteristic micro base of the civilization study.

The roots of civilisation science are also growing from philosophy as a scientific discipline, dealing with the general solution concerning the nature and structure of the existence, sources and legality of human cognition, valuation principles, sense of the world and the place of man in it. As a scientific discipline, the philosophy provides the most important part from many branches of the knowledge. It constitutes the foundation of civilization study, which may be called as a civilization philosophy.

By the use of other science disciplines establishments the civilization science is using them for its own purposes. At the same time, it gives its achievements to other scientific disciplines, inter alia to political science and economy. It is the second side of the civilization study, so called out-

9 R. Paradowska, Idea Rosji - Eurazji i naukowy nacjonalizm Lwa Gumilowa. Próba rekonstrukcji ideologii eurazjatyzmy, Warszawa 1996, p. 12. 
put - emission and influence to its environment. Above all, it gives the knowledge of civilization transformation, and without knowing them, dealing with any aspect of social life would not be complete.

The relationship between the civilization study and political science is specific. ${ }^{10}$ The duties of political science are: setting correctness of political phenomena and processes, identifying sources of conflict and the possibility of the social dispute occurrence, formation of phenomena and processes, and anticipating future development of social phenomena and processes. In cognition, the political science puts the matters comprehensively in interactions; it takes into consideration the variability of reality.

Both the civilization study and the political science are using similar research methods, i.e. principles and methods of systematic researches in order to objective studies of particular reality. Both science disciplines are often using such cognition methods as: system analysis, analogy and historical analysis. One of the most influential theoretical and methodological orientations in these disciplines is the system analysis. The system is understood as constructing conceptual model of structures, i.e. system model. Different area of socio-political reality are interpreted not as scattered sets of isolated elements, but as internally integrated, distinguished from the environment and guided by a kind of regularities in its entirety.

The typical method for the two disciplines is the analogy, called also comparative method. It consists of detecting similarities between the various processes and phenomena, which allow determining the differences between phenomena studies. The main challenge in using the comparative method is to identify the research object. The recognition phenomena should be comparable.

What is important in the study of socio-political phenomena the method of extrapolation, the method of detecting approximate development direction and the method of reflections that transfers the elements of experience from the past in present.

\footnotetext{
10 A. Chodubski, Miejsce nauki o cywilizacji w studiach politologicznych, [in:] Politologia w szkolnictwie wyższym w Polsce. Studia i Materiały, Lublin 1997, pp. 49-57.
} 
Science research methods about politics science depend on the cognition object. Because of having an interdisciplinary nature, in the area of their cognition there are issues with various branches of knowledge, often very distant from each other in the use of diversity methods. It helps to understand a number of diversity issues of narrow specializations. However, as a consequence it leads to generalizations. Using a variety of sociopolitical issues and methods, they allow standing up to current opinion, that generalizations are absolute false parade.

The methodological interpretation of the socio-political phenomena and processes of the past and present allow researchers for distancing themselves from the ideology. Recognizing the importance of ideas in 'time and space', in different socio-economic periods, in various structures of political organization of the society, we should remember that the concept is not only the determinant of philosophical and socio-political systems, but also an architect (creator) of the real world. The conception very often turns people into actions and results in transformation of the reality. Sometimes the idea becomes an object of political manipulation.

In the interpretation of political life's phenomena the importance is attached to the relativism, the relativity of understanding cultural phenomena and processes. It results from the fact that certain phenomena occur in conditions of certain form of existence of the collective life, at some level of the social life. Therefore the term civilization does not apply to the oldest human societies, every human population had participated in some culture but not all took place in the civilization. ${ }^{11}$ The civilization is also a process that arise, develop, affect on other nations, assimilate other peoples' values, and also falls. The awareness of the transcendence of all principles, both material and spiritual allows seeing processes from both past and present. Including the phenomena known as socio-political pathologies, which can be seen by the prism of historical correctness.

Very important category of cognition in this interpretation is transformation. By the term transformation we understand changes that are permanent and dominant in the long term period. The transformations

11 Cf. F. Koneczny, O wielości cywilizacji, Kraków 1935, pp. 34-35; S.P. Huntington, Zderzenie cywilizacji i nowy kształt ładu światowego, Warszawa 1998, ch. II. 
absorb attention of scholars of different science disciplines, as well as general public opinion, including architects of socio-economical and political life. They are a link in the historical process. They enhance cultural development and bring it to higher stage of development. The setback in the process of changes is believed to be natural price of the progress. This fact was already noted in antiquity. Characterizing the world, they spotted that 'any native Greek had not renounced from this belief.12

This interpretation is important to recognize the political reality. The regularity of transformations, as an eternal recurrence of the same forms of power and accompanying them political doctrines, passing one into another in the oscillation between their extremes manifestations - from the most despotic form of government, to the most anarchistic, on the other hand. It was pointed out by the Greek philosopher, Plato (427-347 BC) in his work 'Laws'.

The knowledge of transformation's regularities allows the to plot warning prognosis, from crisis and pathological phenomena. This knowledge allows seeing the process of socio-political dependence of human attitudes and behaviors from management way. This relationship allows dividing the cultural history into development stages. Recently we can indicate, 'waves' crashing together and overlapping: waves of agricultural, industrial and post-industrial civilizations, sometimes called 'the third wave'.

The third wave includes the present. It is considered that it was initiated by the microelectronic and IT revolution. Its face determines mass dissemination of information, faster tempo of life and associated with this: variability transitoriness, diversity, which generate both faster pace of scientific and technical progress, and the pace of implementation of new technologies, by appearing of new, mostly short lived products, as well as creating new jobs, specialties, informal groups, lifestyles, frequent changes of work, places of residence and circle of friends. ${ }^{13}$

12 W. Tatarkiewicz, Historia filozofii, vol. I, Warszawa 1978, p. 172.

13 E. Polak, Przemiany cywilizacji współczesnej w sferze kultury materialnej, Gdańsk 1996, p. 44. 
Figure 1. Platonic conception of the political cycle and corresponding them spiritual attitudes

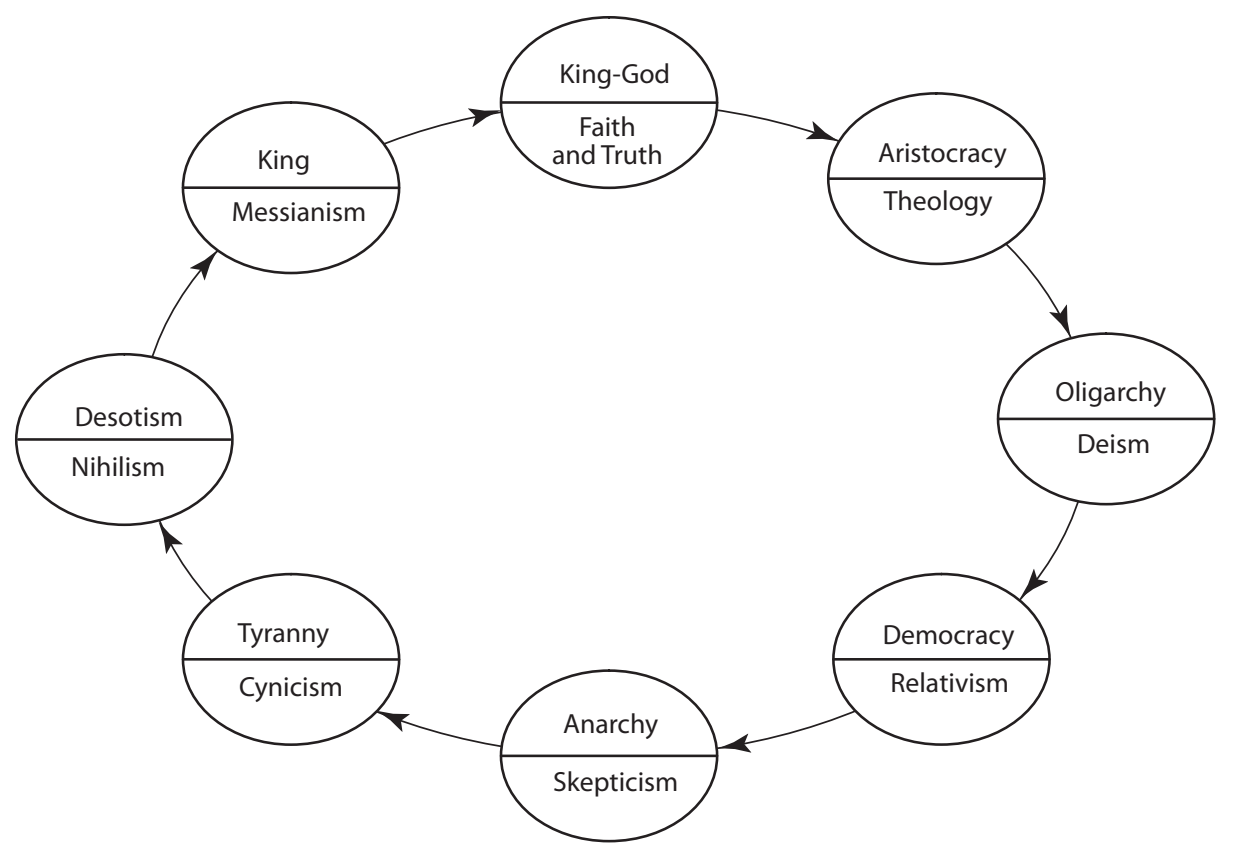

Source: A. Piskozub, Elementy nauki o cywilizacji, Gdańsk 1992, p. 20.

In defining the modern world a lot of attention is paid to the future, it indicates that it will move away from the ideology and from the economy and state of decentralization, the development of various forms of direct democracy, the increase of autonomy and political representation of minority groups, the revival of local initiatives, the strength of individualism, the tolerance and globalization of social life due to the development of IT, communication and transport. It is said that the globalization and localism phenomena will coexist at the same time. Such phenomena and processes as standardization, specialization, synchronization, concentration, maximization and centralization in economical and socio-political life will decided about the globalization. The strength of localism will be set by: individualization of all forms of social life, production and culture. In the political life, the power of minorities will raise, democracy will be 
built semi-direct, the elite will expand, and the modern entity will take a special place in it. ${ }^{14}$

Nowadays, many futurists in the world are dealing with the future foresight. The vision of the future absorbs world's attention, especially the view of John Naisbitt, who presented the civilization called information, and who had distinguished ten main development trends, called megatrends. He described with its help the transition process:

1. From industrial to informational society;

2. From forcible technology to ultra technology;

3. From national to global economy;

4. From short-term to long-term way of thinking;

5. From centralization to decentralization;

6. From institutionalization help to self-help;

7. From representative to participatory democracy;

8. From hierarchy to network;

9. From north to south;

10. From scheme either-or to multiple choice. ${ }^{15}$

These predictions arouse controversies. There are a lot of questions about methods used by the futurists. Significant sources of projections are the news, and of monitoring methods are newspapers. The fact that the most certain way to predict the future is to understand the present is emphasized.

Indeed, any studies of socio-political reality with methods that do not have a verifiability always raise suspicions. Some philosophers advocate for cutting-off from the philosophical desire of formulating general abstract models and they promote the pursuit of revealing science by presentation of more and more factual descriptions, which caused the arguments. ${ }^{16}$ This reality is also observed in many other sub-disciplines

14 A. Toffler, Trzecia fala, Warszawa 1997; A. Chodubski, Jednostka, naród, państwo, [in:] Wprowadzenie do nauki o polityce, B. Szmulik, M. Żmigrodzki (eds.), Lublin 2004, ch. VII.

15 Cf. J. Naisbitt, Megatrendy. Dziesięć nowych kierunków zmieniajacyych nasze życie, Poznań 1997.

16 M. Czarnocka, Dokąd zmierza filozofia nauki?, „Forum Akademickie” 1997, No. 9, pp. 36-37; W.P. Shively, Sztuka prowadzenia badań politycznych, Poznań 2001. 
of politic science. Various allegations are addressed to research synthesis. The consequence of this fact is their continuous lack in Poland. They are replaced by foreign authors' elaborations, which in fact are very superficial. They are depleting the history and reality. ${ }^{17}$

By formulating generalization regarding the present, past and future the need for building brave value judgments is revealed. Mostly, they depend on the experience and personality of researchers. Researcher's opinion, the investigator's independence from the test materials is commonly expressed. However, in the cultural reality the fact that every researcher knows this reality from a particular perspective and with a specified purpose or trend is not seen. In the cognitive generalization it is difficult to imagine organizing facts in logical links, side by side, without a specific research hypothesis and questions, which define the purpose and task of research.

'Impartiality' of the cognition is often noticed to be impossible according to commonly accepted formal methodological requirements in the world, i.e. the obligation to define the aim and task of the study, to formulate research hypothesis and sub-research questions, to determine the state of research, materials and sources, on which the survey was based. In each study and formulation of generalization and theories, very important issue is the problem of trust and distrust. The essential order of scientific cognition is to maintain a reasonable attitude of criticism. ${ }^{18}$

In explaining the function of the phenomena and processes important part fulfills the directive of further rapprochements. It is based on finding common characteristics among the recurring phenomena. By their connection and generalization the science not only deepens the theoretical directions, but it becomes a reliable tool for the cognition. This instruction directs researches on interdisciplinary and cognitive pluralism. It persuades that the problem should not be determined in the observation field of many researchers, discovering it from different time, spatial and methodological perspectives, etc.

17 L. Kuźnicki, Zasadnicze problemy rozwoju nauki w Polsce w najbliższych latach, [in:] Nauka w Polsce w perspektywie XXI wieku..., p. 360.

18 S.D. Tansey, op.cit., pp. 33-36; P. Pawełczyk, op.cit., ch. II. 
In the interpretation of the political processes and phenomena of the past and present, the importance is for both sides, induction and deduction. First of all, the induction allows formulating laws and regularities of the development. It permits to create synthesis of tested reality. The deduction gives the opportunity to learn about the specificity of the cultural processes. The specificity is seen in explaining the political reality as an element of diversity, taking place in the global order, which enriches and makes it more colorful for human beings.

The politic science is using terms typical for humanistic cognition. Using the theory of historical knowledge it creates history of political institutions, using the sociology knowledge - the theory of institutional transformation, on the base of philosophy - political philosophy, using the law and economic establishments - it builds the theory of cultural changes. The cognition is open for needs of present and also for future challenges. Therefore it uses concepts, terms and categories typical for modern world. It is even suspected of using neologisms or tendency to abusing them. Because of the fact that these terms are universal, often borrowed from the Anglo-Saxon vocabulary, they are controversial for narrow specialists. Opposite to the controversy, lexicons and dictionaries of political terms are published.

The conceptual network of political clarification is specifically the result of cognition and terminology: history, philosophy, law, economy and geography, oriented on the view of the political phenomena and processes. In that schedule there is also a typical terminology for the theory of political science.

The political explanation is based on specific material references. It uses highly diverse and varied materials in terms of provenance. Often journalistic, literary and popular science sources are used to reflect scientific. Specialists of narrow disciplines are skeptical to these types of materials, as documents used for scientific knowledge. These specialists approach with a large confidence to archival. They often have a naive approach to the archives, treating them as public institution of faith, to store the materials with full confidence, without going into the origin of their manufacture, production, etc. In the political science interpretation a large distance to all phenomena and events retains, therefore the archives are not under- 
estimating, or they are not overestimate. They serve as a material illustrating the specificity and meanders of socio-political life.

Generally, in the political science' explaining more important are intellectual achievements, of various specialists than the exemplified materials, and further, the most useful cognitive approach provides synthetic analysis than the narrow analysis and causes. The political study often makes interdisciplinary synthesis based on different specialists' establishments, placing too much emphasis on detail arrangements at the cost of the universal phenomena and processes.

In the wake of a specified use of material sources, the question of making formal bibliographic summaries appears in the political science cognition. The political study is based on abandonment from the monographic list sources and literature production, related to the cognitive problem, to show the most important source and material reflecting to the essence of presented problem. It is noted that the lists of monographic bibliographic summaries should be replaced by the information systems. It is also observed that in the diagnosis of certain issues we can observe so called 'too much information'. Their collection and processing is becoming the proverbial ballast for researchers.

In the political cognition the question whether the process of sociopolitical transformation must be interpreted in terms of subject or object categories, often arise. What roles play individuals in political life? The political science considers both categories, subject and object in mutual connection, in the cyber coupling. It recognizes that both, the subject affects on the object, and the object affects on the subject.

The explanation of the political study is experiencing dichotomous reception in the polish scientific community. On the one hand, they are recognized as modern, not affected by the ideology, based on scientific authorities of western civilizations, opened for present and future challenges. And on the other hand, they are rejected by the 'disciplined' thinking, which does not want to accept theoretical and reflective way of thinking, and which pay too little attention to the empirical researches. 


\begin{abstract}
$*^{*} *$
Generalizing above considerations it should be noted that the political science is a discipline of the humanistic cognition, which comes to the needs and challenges of the contemporary socio-political life. It is the object of arguments between the disciplinal and theoretical way of thinking, based on realization of the methodological models, in which the centre of gravity rests on the synthetic and global approaches, most of all, on the humanist interpretation. The interpretations of the political science, next to strictly scientific wisdom, provide also the practical knowledge: diagnosis and prognosis. An important fact of the interpretation of the political study, happening nowadays are radical transformations of political science, which consequences are crisis of the family institution, health system, social organizations, systems of value, and most importantly, political system that loses the public confidence. The explanation of the political study also plays significant educational task, not only explains the world, but also teaches its understanding and transformations.
\end{abstract}

